\title{
The Comparison of Students' Physical Fitness Level
}

\author{
Rafdi Primaharsyah*, Khairunnas, Sefri Hardiansyah \\ Sport Education Program, Faculty of Sport Science, Universitas Negeri Padang, Indonesia \\ ${ }^{*}$ Corresponding author. Email: rafdiprimaharsyah1992@gmail.com; khairunnas@gmail.com; \\ hardiansyah@fik.unp.ac.id
}

\begin{abstract}
The purpose of this study is to determine the differences of elementary students' physical fitness level between students in SDN 05 Sungai Beremas West Pasaman Regency and students in SDN 25 Padang City. This is an ex post facto design using comparative research method. This research involves 20 students from SDN 05 Sungai Beremas and 20 students from SDN 25 Padang. The data were collected using Physical Fitness Tests to students aged 10-12. The data were analyzed using t-test. The result showed the average level of students' physical fitness in SDN 05 Sungai Beremas was 15.75 and the average level of students' physical fitness in SDN 25 Padang was 13.95. From the results of the study, it can be concluded that the level of students' physical fitness in SDN 05 Sungai Beremas West Pasaman Regency is better than students' physical fitness in SDN 25 Padang.
\end{abstract}

\section{Keywords: Physical fitness, Elementary students, Physical Fitness Test}

\section{INTRODUCTION}

Physical Education Sport and Health is one of the subjects in the elementary school curriculum. The existence of this subject in all levels of primary schools, it is expected that all elementary school students have the skills and have good physical fitness but in reality there are still many students havelow physical fitness. Education is essentially an effort done consciously, which is planned and sustainable towards a change, progress, and improvement for creatinghuman resources in the development of Indonesia as a whole, as it concerns the preparation of human resources as the executor of future development. This is in line with the demands of the National Education System regulations (USPN) no. 20 of 2003 which reads as follows:

"Education is a fundamental activity to promote society and its citizens. Education serves to create the character and dignity of the nation in order to educate the nations, aims to develop the learners into human beings who believe and piety to Allah SWT, having morals, healthy, knowledgeable, capable, creative, independent, democratic and responsible citizens"[1].

Based on the description above, it can be said that the purpose of education is basically to improve the quality of human resources and the establishment of Indonesian who is ready intellectually, mentally, physically, and spiritually in order to face the future. The effort to realize it can be done through physical education at school, because by doing sports activities that are well implemented and directed, guided and developed properly, it is very meaningful and useful in the efforts to achieve the goal of education, especially Penjasorkesin improving students'physical fitness in the implementation of teaching and learning activities at school. Physical fitness is more focused on physiological fitness that is the body'sability to adjust the function of the body in physiological limits on environmental circumstances (height, humidity, temperature and so on) [2][3][4].

Related to this, being developed the thoughts like the steps in physical development of students' physics. These steps include the improvement of nutritional status, health status, and physical fitness. But in reality the concern for these three problems have not been fully done because it is influenced by various factors in society such as: education, social, and economics that ultimately determine the behavior of the community. Based on the facts mentioned above from the observations encountered by the researcher in the field where SDN 05 Sungai Beremas is located in the coastal area, with the average economic condition of the middle-low society, and in this school the students go to school on foot and most students come from indigenous communities. The students' parents is mostly fishermen. After school the students continue their physical activities by helping their parents or playing on the beach nearby, and almost can be said after school no students are taking private lessons. This can greatly affect the physical fitness of students at this school.

While the condition in SDN25 Padang is extremely differentfrom SDN 05 Sungai Beremas, where this school is located in urban area. In students' daily activities, most of them go to school drived by their parents or usingpublic transportations, and after school some students still join 
various kinds of tutoring or studying in the mosque, so it can be said the physical activity of students is less, but it can not be directly concluded which school students' who have better level of physical fitness. The differences in physical fitness can be influenced by several factors likenutrition, school condition or environment, economic condition, student physical activity, school health and school environment, students'trained level and habits that can differentiate students' physical fitness. Based on the above descriptions, researcher wants to reveal the real facts by conducting a research entitled: "Comparison of the Physical Fitness of Elementary School Students of 05 Sungai BeremasWest Pasaman with Elementary School Students of 25 Padang". Hopefully this research can provide some inputs for Penjaskesteachers. Being used to restore and improve the students' physical fitness; with being healthy and fresh, so the students can follow the teaching and learning process well and smoothly.

The notion of physical fitness is diverse and depends on one's point of view on physical fitness. In terms of etymilogis, the physical fitness comes from the translation of english phrase "physical fitness". Physical means physic and fitness means fit or ability (fit = fit, worthy, or capable), so physical fitness means one's physical ability[5]. A person in a fit condition, he will have a healthy body to defend themselves from outside influences. This means that one is able to resist external influences without reducing the efficiency of the body condition and the harmony of organism processes in the body.

"Physical fitness is an aspect, which is the physical aspect of total fitness that gives a person the ability to live a productive life and can adapt to each physical stress[6]. Physical fitness is the ability of one's body to perform daily tasks without causing significant fatigue[7].

"An ability to perform normallyin daily activities with a passionate and full of alertness, without experiencing significant fatigue and still have energy reserves to enjoy leisure activities as well as emergency events who come suddenly "[8]. It can be concluded that physical fitness is a condition when the body is able to fulfill its daily duties properly and efficiently without feeling significant fatigue, the body still has energy reserves, either to cope with sudden emergencies, or to enjoy leisure with an active recreation. Based on the opinionabove, it means that physical fitness is a mirror of the systems functions ability of the body that can realize the improvement of life quality in every physical activity done.

The factors that affect one's physical fitness level are [9]:

1. Food

Food is primary need of every human being, but to keep the body healthy, the food must contain the several conditions below: 1) Can becomebody maintenance, 2) Can provide for body growth, 3) Can replace the worn and damaged body condition, 4) Contains the elements needed by the body 5) Can bean energy source.

\section{Exercise}

Exercise is a form of physical activity that has a positive influence on the level of human's physical fitness when being done correctly, because by doing exercises all the organs of the body will work well and trained. Most of today's people tend to be preoccupied with daily activities that contain less movement; meanwhile the exercise can free us from stress, and can accelerate blood circulation so humans' mind can be fresher and the physic remainsfit

\section{Age}

The older a person the lower his or her fitness level will decrease, having problems with his body such as muscle loss, the heart size is shrinking and the strength of the pump decreasing, the stiffening of the arteries, the skin turning thin and its activity becomes slow.All of these problems happenbecause the function of body's organs become weak, but the decline can be slowed by doing an exercise when stillyoung, weak body condition because of agingmakesthe decrease of physical fitness level.

\section{Life Habits}

Every person has different life habits depending on the level of daily activities, healthy living habits is the arrangement between exercise, rest and personal habits to keep the hygiene; in psychologically work activities that are more than usual will affect the one's brain work, a person who usually lives relaxed and has a low activity if one day having a high activity at the beginning they will usually experience stress, but after a certain period of time will adjust.

\section{Environmental factors}

The environment is the place where a person settles and lives, in this case concerning the physical environment, as well as social from the environment nearby to the environment where the students learn. The quality of one's health can be seen with the condition of its physical fitness status.

\section{Nutrition consumed}

Nutrition is very important in everyday life. Everyone to fulfill their every day nutritional needs will vary, according to the level of one's economic ability. If the nutrients consumed in accordance with the nutritional adequacy rate, any work done certainly will not cause a bad effect for everyone.

\section{METHODOLOGY}

This research belongs to comparative research with the aim to see the difference and the comparison of students' physical fitness level of SDN 05 Sungai Beremas with SDN 25 Padang. The sample in this study was class V students, total 20 persons from SDN 05 Sungai Beremas and 20 students of SDN 25 Padang.

\section{RESULT}

The data analyzed in accordance with the factual findings in the field as it is. The result of this analysis is a description of "Comparison of Students' Physical Fitness Level ofSDN 05 Sungai Beremas with SDN 25 Padang". 


\subsubsection{Level of Physical Fitness of Elementary School Students 05 Sungai Beremas}

The result of measurement using TKJI test to the students of SDN 05 Sungai Beremas consists of 20 persons, shows that the mean is 15.75 , median is 16,17 standard deviation mode is 1.92 , the highest score is 19 and the lowest score is 12. For more details the data result of students' physical fitness research of SDN 05 Sungai Beremas can be seen in diagram 1 .

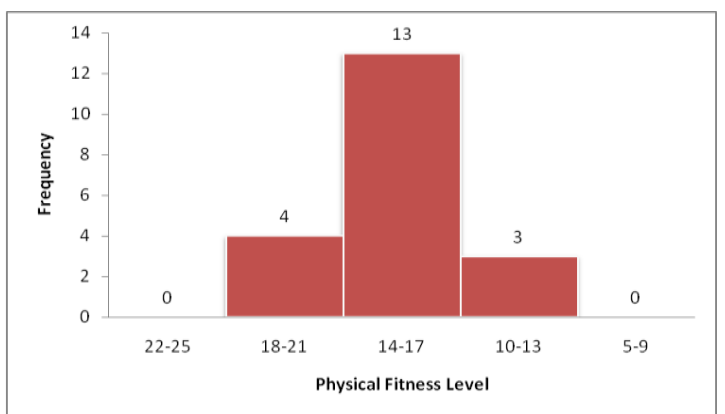

Figure 1. Level Physical Fitness of Students SDN 05 Sungai Beremas.

From the diagram above it can be seen that no students have physical fitness level at 5-9 intervals that is in least category, whereas at 10-13 intervals there are 3 students $(15 \%)$ that are in less category, and at 14-17 intervals 13 students $(65 \%)$ are in moderate category, at 18-21 intervals there are 4 persons (20\%) with good category, while at 22 25 intervalswhich is in excellent category no studentsis in that interval. The data from the table is then presented into the histogram diagram, as follows:

3.1.2. Level of Physical Fitness of Elementary School Students 25 Kota Padang

The result of the measurement using TKJI test to the students of SDN 25 Padang consists of 20 persons, it shows that the mean is 13.95 , median is 14,15 standard deviation mode is 1.61 , the highest score is 17 and the lowest score is 11 . For more details results of students' physical fitness research of SDN 25 Padang can be seen in diagram 2.

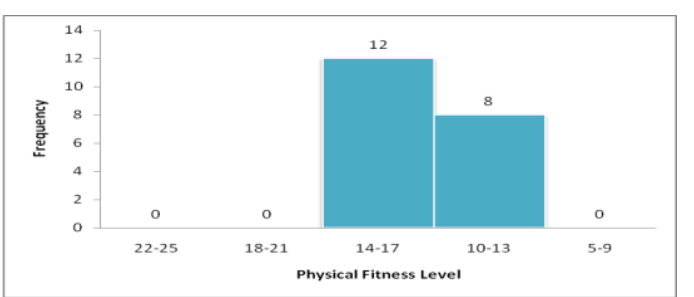

Figure 2. Physical Fitness of SDN 25 Padang students.

From the diagram above it can be seen that no students have physical fitness level at 5-9 intervals that is in least category, whereas at 10-13 intervals there are 8 students $(40 \%)$ that are in less category, and at 14-17 intervals are 12 students $(60 \%)$ that are in the moderate category, whereas at 18-21 intervals and 22-25 intervals no students have physical fitnesslevelin the intervals. The data from the table is then presented into the histogram diagram, as follows:

3.1.3. Hypothesis Test

As explained in the previous chapter, the hypothesis proposed in this study is "The level of the students'physical fitness of SDN 05 Sungai Beremas is better than the students of SDN 25 Kota Padang". The hypothesis was tested by using t-test at significant level $\alpha$ $0.025 \%$. From the result of data analysis obtained $t_{\text {count }}$ (3.23) $>\mathrm{t}_{\text {table }}$ (2.021), which means that there is a significant difference between physical fitness level of SDN 05 Sungai Beremas students with SDN 25 Padang. Based on the average score, the average of SD Negeri 05 Sungai Beremas students is 15.75 that is larger than the average of SDN 25 Padang students, which is 13.95. This proves that the physical fitness level of SDN 05 Sungai Beremas students is better than SDN 25 Padang students.

\section{DISCUSSION}

Based on the measurement results, it can be concluded that the physical fitness level of SDN 05 Sungai Beremas students is better than SDN 25 Padang students. Given this reality, it is clear that students' physical fitness in different neighborhoods can lead to physical fitness level differences. The environment is the place where a person settles and lives, in this case concerning the physical environment, as well as social from the environment nearby to the environment where the students learn. The quality of one's health can be seen with the condition of its physical fitness status. Someone who has a good physical fitness will be able to work for a long time, it also occurs toa student. Fit students will enjoyto study and not easily being tired in following the lessons given by the teacher.While for students who are not fit will be easily tired and sleepy and not enthusiastic in learning process. Physical fitness is the body'scondition to be able to perform daily activities without experiencing significant fatigue[10]. The person with the best physical fitness has the greatest energy reserves, and those whose the worst physical fitness has the least energy reserves. Every person has different lifehabits depending on the level of daily activities, healthy living habits is the arrangement between exercise, rest and personal habits to keep the hygiene. In psychologically work activities that are more than usual will affect the one's brain work, a person who usually lives relaxed and have a low activity if one day having a high activity at the beginning they willusually experience stress, but after a certain period of time will adjust.

The geographical condition or natural condition of SDN 05 Sungai Beremas is located in rural areas and on the coast. The living conditions of students in the countryside and the lack of transportation to get to school cause the students have to walk to get to school. Then, the activities of SDN05 Sungai Beremasstudents while at school during the break often do some movement activities. They love to play with their friends and also do activities outside the school. Physical activity they do, such as helping parents to work in the fields, playing on the beach, then in the afternoon most male students SDN 
05 River Beremas play football, it canobviously affect the physical fitness of students in this school, because they involve more physical movement.

In contrast, the geographical condition of SDN 25 Padang is located in the coastal suburbs and also near downtown. The crowded population makes the government provide many transportation facilities in this area for daily work activities so that the students go to school drived by their parentsin order to be safe. Activities done by students of SDN 25 Padang at the break are less involved the physical movement. In general, they only play a gamethat does not require much move, and after school they alsodo not do much physical activity. Because there is no work to do that demands physical strength, they mostly just play electronic games in their own homes.

From the above description, the best teachers of physical education who teach in elementary school, can choose a good teaching method in providing physical education lessons and related to the situation and conditions encountered. It is expected that with the anticipation done by the teachers, will be able to improve students physical fitness. In addition, PJOK teachers should also consider that nutritional factors that will also affect the level of students' physical fitness such as nutritional intake and daily food consumption. If the knowledge of students or parents are less aware of health especially about the information of nutrition menus, this can affect the students' physical growth and also likely affect the level of students' physical fitness.

Thus, to increase a very good physical fitness, every student is expected to perform these activities properly in accordance with the portion or procedure that has been set and consider the factors that influence the students' physical fitness. Physical fitness plays an important role in the students' life, because students who have a good level of physical fitness will certainly have high productivity and can learn effectively and efficiently. This is certainly needed by students since students who have good physical fitnesslevel will be able to perform activities with passion, concentration, so they can receive the lessons well.

To improve and maintain physical fitness can be done through physical education activities at school or with aerobic exerciseoutside school activities. Physical activity in school includes various activities that can increase students' physical fitness, such as; running, jumping, rolling, gymnastics fitness and so on that involve physical movements and psychic so the students can keep the spirit and joy. Aerobic exercise can be jogging, swimming, walking, cycling, jumping rope, playing football. This exercise can be done continuously. These exercises can also improve and maintain cardiorespiratory or aerobic fitness.

From the above explanation it can be argued that the physical fitness has the important role in the students' life, especially to improve students' learning activity for better. Therefore, for the students personally it is important to increase the physical fitness to be better through various physical activities that can be done in accordance with the rules applied.

\section{CONCLUSION}

Based on the results of the research that has been described in the previous chapter can be put forward the conclusion that is the physical fitnesslevel of SDN 05 Sungai Beremasstudents is better than the physical fitnesslevelof SDN 25 Padangstudents.

\section{REFERENCES}

[1] Undang-Undang RI No. 20 Tahun 2003. Sistem Pendidikan Nasional. Jakarta: Cipta Jaya. 2003, pp 25.

[2] Arsil. "Pembinaan Kondisi Fisik". Padang: FIK UNP. 2008, pp 18-44.

[3] N Ihsan, S Sepriadi, S Suwirman. "Hubungan status gizi dan motivasi berprestasi dengan tingkat kondisi fisik siswa pplp cabang pencak silat sumatera barat". Sporta Saintika 3 (1), Sept 2018, pp 410-422.

[4] N Ihsan. "The analysis of the physical condition, will pencak silat construction training center students (PPLP) of West Sumatra”. International Seminar of Sport Culture and Achievemalet, April 2014, pp 307-421.

[5] Syarifuddin Aip, Muhadi. "Pendidikan Jasmani Dan Kesehatan”. Jakarta: Depdikbud. 1992, pp 516.

[6] Arsil. "Tes Pengukuran Dan Evaluasi Pendidikan Jasmani Dan Olahraga”. Padang: FIK UNP. 2009, pp 9-55.

[7] Depdikbud. "Ketahuilah Tingkat Kesegaran Jasmani Anda". Jakarta: Depdikbud Pusat Kesegaran Jasmani Dan Rekreasi.1996, pp 1-42.

[8] Gusril. "Beberapa Faktor Yang berkaitan Dengan Kemampuan Motorik Siswa Sekolah Dasar Negeri Kota Padang”. Disertasi. Jakarta. UNJ. 2004, pp 25-46.

[9] Suyadi. "Korelasi Antara Tingkat Kesegaran Jasmani (Physical Fitness) Dan Kesehatan Mental (Mental Hygiene) Dengan Prestasi Belajar Pendidikan Jasmani (Penjas) Siswa Kelas V SDN 2 Pegulon Kendal Tahun Pelajaran 2004/2005" .Skripsi. Semarang. UNNES. 2006, pp 17-53.

[10] Hardiansyah Sefri. "The Influence Of Circuit Training Method On The Enhancement Of Physical Fitness Of Sports Education Department Students". Proceedings The $1^{\text {st }}$ Yogyakarta international seminar on health, physical education, and sports science: Yogyakarta. January 2017, pp 1-7. 